\title{
The Relationship between State and Trait Anxiety with Career Indecision of Undergraduate Students
}

\author{
Fadaei Nasab Mojgan (Corresponding author) \\ Faculty of Educational Studies, University Putra Malaysia \\ 43400, Serdang, Selangor, Malaysia \\ Tel: 60-172-728-653 E-mail: fadaei77@gmail.com \\ Rusnani Abd. Kadir \\ Sidek Mohd. Noah, Siti Aishah Hassan \\ Faculty of Educational studies \\ University Putra Malaysia, 43400, Serdang, Selangor, Malaysia
}

Saidian Soheil

University of Khoramshahr, 669, Khoramshahr, Iran

Received: February 12, 2011 Accepted: February 16, 2011 doi:10.5539/ies.v4n3p31

\begin{abstract}
The aim of this study was to determine the relationship between state and trait anxiety with career indecision of Iranian undergraduate students. According to the literature anxiety has a strong impact on career indecision among students. However, there is controversy in research findings regarding the contribution of state and trait anxiety to career indecision. Despite many studies on the relationship between state and trait anxiety with career indecision, very limited research has been conducted in this area among Iranian students. For this purpose, 150 undergraduate undecided students from 3 universities in Khozestan Iran, completed the career decision scale (CDS), and the State Trait Anxiety Inventory (STAI). Results of regression analysis showed that trait anxiety had a stronger impact on career indecision than did state anxiety. In addition, the relationship between anxiety components and career indecision was reported as positive. Implications for further research are discussed in the paper.
\end{abstract}

Keywords: Career indecision, State anxiety, Trait anxiety, Iranian students

\section{Introduction}

Deciding upon a career is one of the most important areas of decision making. Career indecision has been one of the central research issues of counseling and psychology, especially in young adults who are in the midst of making critical life decisions. It is defined as one's inability to make a decision about the career he/she wishes to pursue (Osipow, 1976).

Gordon (1998) believes students with career indecision feel paralyzed, unclear, and anxious; and even if the choices have already been made, they are still unable to make commitment to their academic choices.

There is controversy in the nature of career indecision among scholars. Krumboltz (1992) believes that using the term 'undecided' for students may have a detrimental effect on their mental health and happiness. He further suggests using a positive term for those who take additional time to make a decision would cause a less anxiety provoking situation for students. Krumboltz also believes that the consequences of career indecision are not invariably negative (pp. 240). However, Callanan \& Greenhaus (1992) view career indecision as a serious problem which doesn't always act as facilitator of decision making process. Therefore, these arguments stress the multidimensionality of career indecision.

Career indecision has been linked to factors such as anxiety (Fuqua, Seaworth, Newman, 1988; Gribben and Keitel 1992; Campagna and Curtis, 2007), family interaction patterns and attachment (Downinng and Nauta, 2010), identity (Tokar, Withdrow and Hall, 2003) and career decision self efficacy (Betz, Klein, \& Taylor, 1996; Guay, Senecal, and Fernet, 2003). This paper's focus was the contribution of state and trait anxiety on career indecision 
among Iranian undergraduate students.

Anxiety has been shown to influence many types of decisions including those related to career. Crites (1974) suggested that high levels of anxiety may hinder effective career decision making and development. Early studies showed students with higher levels of anxiety experienced higher indecision (Hawkins, Bradley \& White, 1974; Kimes \& Troth, 1974).

As the concept of career indecision became more defined, the role of anxiety on career indecision showed significant on the literature, and distinction between state and trait anxiety became more commonplace (Spielberger et al., 1983). However, there is inconsistency in the findings related to the influence of state and trait anxiety on career indecision. In their research on the relationship between state and trait anxiety with different components of career indecision, Fuqua, Seaworth and Newman (1988) reported anxiety is significantly related to some components of career indecision. In addition, the results showed higher correlation between trait anxiety and indecision factors related to lack of information and perceived barriers to choice.

By contrast, Campagna \& Curtis (2007) reported that state anxiety is a stronger predictor of career indecision. Nevertheless, few studies have been conducted on the impact of anxiety to career indecision in Asian students particularly Iranians. In addressing this gap it would be important to examine the role of anxiety components on career indecision of Iranian students.

Leong and Leung (1994) believe Asian American parents have high expectations about their children's career choices. Having a strong obligation towards meeting their parents' expectations in choosing prestigious careers, young adults are under a lot of pressure and as Krumblotz (1992) suggests it could be one possible source of anxiety.

Iranian students have the same situation in choosing such careers. High competition in entering universities and the job market, and the other side lack of legitimate mechanism to teach them career decision making skills and planning have made many students confused, uncertain, and anxious about their future career. Therefore, present study aimed to investigate the impact of state and trait anxiety on the career indecision of Iranian students. Based $n$ the previous research findings it is predicted that these factors has significant impact on career indecision.

\section{Methodology}

\subsection{Participants and Procedure}

The participants of this study comprised of 150 undergraduate freshmen and sophomore students (female and male), studying at 3 universities in Khozestan. In the first phase of sampling in order to identify undecided students from those who were decideded, the Career Decision Scale was administrated to all of the undergraduate freshmen and sophomores. After identifying undecided students, 150 of them were randomly selected and questionnaires were distributed and collected during their regular classes. The subjects ranged from 17 to 21 years of age.

\subsection{Instrument}

Two instruments were used for the purpose of this study as follow:

i. The Career Decision Scale (CDS, Osipow et al., 1976): The CDS is an instrument that identifies barriers hampering individuals from making career indecision. This scale consists of 19 items, in which items 3-18 are indecision scale used in the study. Test-retest reliability of indecision scale has been reported as $0.90,0.82$ by Taylor and Pompa (1990). Osipow (1987) reported two retest correlations of .90 and .82 for the indecision scale for the two groups of college students. Career Decision Scale has been employed in a large number of studies which have directly or indirectly examined various aspects of its validity.

Osipow and Schweikert (1981) examined the relationship of the CDS with the Assessment of Career Decision Making (ACDM). The results showed significant negative correlation between the indecision scale and the ACDM.

ii. The State and Trait Anxiety Inventory (STAI, Spielberger et al., 1977): The STAI was used to measure state and trait anxiety. The inventory was developed for measuring two distinct components of the concept of anxiety. The STAI consists of two scales, State and Trait anxiety with twenty items in each scale, presented on a 4-point Likert scale.

The reliability of both the Trait anxiety and State anxiety ranged from .73 to .86 and reported satisfactory for research purposes. Evidence of concurrent (.41 to .85), convergent and divergent (.64 to .81$)$, as well as construct validity (.60 to .94$)$ are reported (Spielberger et al., 1983).

\section{Results}

Table 1 presents the mean, standard deviations, and correlations for the measured variables. The CDS correlated positively to both components of anxiety, with the stronger correlation to trait $(r=.62, p=.001)$ compared to state 
anxiety $(r=.33, p=.001)$. It implies that higher level of students' anxiety, leads to higher career indecision. In addition, a strong positive correlation was found between state and trait anxiety $(r=.71, p=.001)$, indicating the independent correlation of career indecision with state and trait anxiety.

The results of multiple linear regression (MLR) analysis shown in table 2 demonstrated that both state and trait anxiety were significantly contributed to the variation of career indecision, with stronger impact of trait anxiety $(b$ $=.78, p=.001)$, compared to state anxiety $(b=.22, p=.001)$. It also suggests that one standard deviation increase in trait anxiety is followed by .78 standard deviation increase in career indecision, likewise one standard deviation increase in state anxiety is followed by .22 standard deviation increase in career indecision.

In addition, the adjusted R-squared value of .40 indicated that state and trait anxiety explained about $40 \%$ of the variance in the career indecision which shows a respectable result in social science.

\section{Discussion}

The purpose of the present study was to investigate the role of state and trait anxiety on the career indecision of Iranian students. The findings of this study supported the previous research in existing a strong positive correlation between state and trait anxiety with career indecision (Fuqua, Seaworth, \& Newman,1988; Hartman et al., 1985; Kelly \& Pulver, 2003).

In addition, when regression analysis was conducted to find out the independent contribution of state and trait anxiety to career indecision, trait anxiety was a stronger predictor compared to state. There is controversy in research findings reporting state anxiety (Campagna \& curtis, 2007; Woodburry, 1997; Gribben \& Keitel, 1992) or trait anxiety (Obana, 2007) as the stronger predictor of career indecision.

However, the result of this study was inline with Obana's report regarding the greater impact of trait anxiety on the career indecision of Japanese students. It seems that a more stable component of anxiety has higher impact on the career indecision among Iranian students like Japanese.

According to Medonca and Siess (1976) trait anxiety presents itself as an antecedent of career indecision. Trait anxiety as related to concepts like neurotism, may inhibit the students' ability of carrying out necessary tasks that facilitate the process of effective career decision making. Likewise, a more transient and present feeling of anxiety (state), may be the consequence of inadequate information and skills related to career decision making.

Therefore, in light of the present results if university counselors ignore students' psychological and personal issues related to career indecision; may fail to invest time and money by only focusing on information-gathering and other career activities. It would be beneficial to explore the possible sources of anxiety in either individual or group counseling sessions. As mentioned earlier, the important role and high expectations of family members and significant others that maybe the source of pressure and anxiety in Iranian students, should be considered. Evidence of applying anxiety and stress management and coping skills as effective intervention strategies in dealing with anxious undecided students has been presented in literature.

Finally, further research is needed to investigate the influence of other factors on career indecision among a large number of Iranian students, in order to help them effectively in dealing with one of the most critical decisions in life called 'career'.

\section{References}

Betz, N., Klein, K., \& Taylor, K. (1996). Evaluation of short form Career Decision Making Self Efficacy. American Counseling Association.

Callanan, G. A., \& Greenhouse, J. H. (1992). The career indecision of managers and professionals: An examination of multiple subtypes. Journal of Vocational Behavior, 41, 212-231

Campagan, C. G., \& Curtis, G. J. (2007). So worried I don't know what to be: Anxiety is associated with increased career indecision and reduced career certainty, Australian Journal of Guidance and Counseling, 17, 91-96

Crites, J. O. (1974). Career counseling: A review of major approaches.Counseling Psychologist, 4, 3-23

Downing, M. H., \& Nauta, M. M. (2010). Separation-individuation, exploration, and identity diffusion as mediators of the relationship between attachment and career indecision. Journal of Career Development, 36(3), 207-227

Fuqua, D. R., Newman, J. L., \& Seaworth, T. B. (1988). Relation of state and trait anxiety to different components of career indecision. Journal of Counseling Psychology, 33, 154-158

Gordon, V. N. (1998). Career decidedness types: A literature review. The Career Development Quarterly 46(4), $386-403$ 
Gribben, C. A., \& Katel, M. A. (1992). Career indecision, anxiety, and social problem solving: A path analytical model. Paper Presented at the Manual Convention of the American Psychologist \& Association, Washington DC.

Guay, F., Senecal, C. G., L., \& Fernet, C. (2003). Predicting career indecision: A self determination theory. Journal of Counseling Psychology, 50, 165-177

Hartman, B. W., Fuqua, D., Blum, C., \& Hartman, T. (1985). A study of the predictive validity of the Career Decision Scale in identifying longitudinal patterns of career indecision. Vocational Behavior, 2, 202-209

Hawkins, J. G., Bradley, R. W., \& White, G. W. (1977). Anxiety and the process of deciding about a major and vocation. Journal of Counseling Psychology, 24, 398-403

Kelly, K. R., \& Pulver, C. A. (2003). Refining measurement of career indecision types: A validity study. Journal of Counseling and Development, 81, 445-454

Kimes, H. G., \& Troth, W. A. (1974). Relationship of trait Anxiety to career decisiveness. Journal of Counseling Psychology, 21, 277-280

Krumboltz, J. D. (1992 ). The wisdom of indecision. Journal of Vocational Behavior, 41, 239-244

Leong, F. T., \& Leung, S. A. (1994). Career Assessment with Asian Americans. Journal of Career Assessment, 2(3), $240-257$

Mendonca, J. D., \& Seiss, T. F. (1976). Counseling for indecisiveness: problem solving and anxiety management training. Journal of Counseling Psychology, 23, 339-347

Osipow, S. H., Carney, C., Winer, G., Yanico, J., \& Koschier, M. (1976). The Career Decision Scale (3 ed.). Columbus: Marathon Consulting and Press.

Osipow, S. H., \& Schweikert, D. (1981). The Career Decision Scale: A test of concurrent validity Psychological Reports, 4, 759-761

Osipow, S. H. (1987). Manual for the Career Decision Scale. Odessa, FL: Psychological Assessment Resource.

Obana, M. (2007). Factors predicting career indecision of Japanese liberal arts, education, and business majors. The University of Memphis, Memphis.

Spielberger, C. D., Gorsuch, R. L., \& Lushene, R. E., Vagg. P. R., \& Jpcobs, G. A. (1977). State Trait Anxiety Inventory, Palo Alto, CA: Consulting Psychologists Press.

Spielberger, C. D., Gorsuch, R.L., Lushene, R. E., Vagg. P. R., \& Jpcobs, G. A. (1983). Manual for the state-trait anxiety inventory. PaloAlto, CA: Counseling Psychologist press.

Tokar, D. M., Withrow, J. R., Hall, R. J., \& Moradi, B. (2003). Psychological separation, attachment security, vocational self Concept crystalization, and career indecision: A structural equation analysis. Journal of Counseling Psychology, 50(124), 3-19

Taylor, K., \& Pompa, J. (1990). Construct validity of Career Decision Making Self Efficacy Scale and the relationship of CDMSE to the vocational indecision. Journal of Vocational Behavior, 37, 17-31

Wilson, L. (2000). The Relationship between parental attachment, career decision making self-efficacy, gender, race and career indecision. The Florida State University, Florida.

Woodbury, C. A. (1997). The Relationship on Anxiety, Locus of control, and Hope to Career Indecision of African American College Students. Howard University, Washington, DC. 
Table 1. Means, Std. Deviations, and correlations between variables

\begin{tabular}{rccccc}
\hline & $M$ & $S D$ & 1 & 2 & 3 \\
\hline 1. Career indecision & 20.00 & 4.25 & 1.00 & $.62^{* *}$ & $.33^{* *}$ \\
2. Trait anxiety & 45.39 & 9.82 & & 1.00 & $.71^{* *}$ \\
3. State anxiety & 46.18 & 8.58 & & & 1.00
\end{tabular}

Note: $\mathrm{N}=150,{ }^{* *} p<.001$

Table 2. Estimates of coefficient for the model

\begin{tabular}{cccccc}
\hline Variables & $\begin{array}{c}B \text { (unstandardized } \\
\text { Coefficient) }\end{array}$ & Std. Error & $\begin{array}{c}B \text { (standardized } \\
\text { Coefficient) }\end{array}$ & $T$ & $P$-value \\
\hline Constant & 9.72 & 1.50 & .78 & 6.46 & .001 \\
Trait anxiety & .33 & .03 & .78 & 8.67 & .001 \\
State anxiety & .10 & .04 & .22 & 2.50 & .001 \\
\hline
\end{tabular}

Note: $R=.64, R^{2}=.41$, Adj. $R^{2}=.40, F$-Statistics $=51.5$ 